\title{
Toxicity against Artemia salina of the zoanthid Palythoa caribaeorum (Cnidaria: Anthozoa) used in folk medicine on the coast of Pernambuco, Brazil
}

\author{
Liany Figuerêdo de Andrade Melo ${ }^{1 *}$ \\ Claudio Augusto Gomes da Camara ${ }^{2}$ \\ Lourinalda Luiza Dantas da Silva Selva de Oliveira ${ }^{3}$ \\ Jeanne Claine de Albuquerque Modesto ${ }^{1}$ \\ Carlos Daniel Pérez ${ }^{1}$ \\ 'Núcleo de Biologia, Centro Acadêmico de Vitória, Universidade Federal de Pernambuco \\ CEP 55608-680, Vitória de Santo Antão - PE, Brasil \\ ${ }^{2}$ Departamento de Ciências Moleculares, Universidade Federal Rural de Pernambuco \\ CEP 52171-900, Recife - PE, Brasil \\ ${ }^{3}$ Unidade Acadêmica de Serra Talhada, Universidade Federal Rural de Pernambuco \\ CEP 56900-000, Serra Talhada - PE, Brasil \\ *Author for correspondence \\ lianymelo@gmail.com
}

Submetido em 30/09/2011

Aceito para publicação em 07/05/2012

\section{Resumo}

Toxicidade diante de Artemia salina do zoantídeo Palythoa caribaeorum (Cnidaria: Anthozoa) usado na medicina popular no litoral de Pernambuco, Brasil. Palythoa caribaeorum é um zoantídeo cujo muco é tradicionalmente usado por comunidades de pescadores do litoral sul do estado de Pernambuco como agente anestésico e anti-inflamatório e para o tratamento de feridas tópicas. A fim de avaliar uma possível toxicidade, extratos hexânicos e etanólicos do zoantídeo coletado nas praias de Piedade (PCP-H; PCP-E), Guadalupe (PCG-H; PCG-E) e Suape (PCS-H; PCS-E) foram testados diante de larvas de Artemia salina. Entre os seis extratos testados, PCP-H, PCP-E, PCS-H e PCS-E demonstraram baixa toxicidade, com valores de $\mathrm{CL}_{50}$ acima de $250 \mu \mathrm{g} / \mathrm{mL}$. Por outro lado, PCG-H $\left(80<\mathrm{CL}_{50}<250 \mu \mathrm{g} / \mathrm{mL}\right)$ foi categorizado como moderadamente tóxico, enquanto PCG-E $\left(\mathrm{CL}_{50}<80 \mu \mathrm{g} / \mathrm{mL}\right)$ foi considerado altamente tóxico, com seu grau de toxicidade próximo ao da droga padrão ciclofosfamida $\left(\mathrm{CL}_{50}=19,7 \mu \mathrm{g} / \mathrm{mL}\right)$. Os resultados indicam a presença de compostos tóxicos no zoantídeo coletado em Guadalupe e sugerem cautela no uso de $P$. caribaeorum como medicamento popular. As variações encontradas nos extratos das populações pernambucanas de $P$. caribaeorum testadas corroboram relatos anteriores de que a ação tóxica desse zoantídeo não é inerente à espécie, mas influenciada por condições ambientais e organismos associados.

Palavras-chave: Artemia salina; Extratos orgânicos; Pernambuco; Toxicidade; Zoanthidea

\section{Abstract}

Palythoa caribaeorum is a zoanthid whose mucus is traditionally used by fishermen communities on the southern coast of the state of Pernambuco as an anesthetic and anti-inflammatory agent, as well as for the 
treatment of topical wounds. In order to evaluate a possible toxicity, hexane and ethanol extracts of the zoanthid obtained from the beaches of Piedade (PCP-H; PCP-E), Guadalupe (PCG-H; PCG-E), and Suape (PCS-H; PCS-E) were tested against Artemia salina larvae. Among the six extracts tested, PCP-H, PCP-E, PCS-H, and PCS-E showed low toxicity, with $\mathrm{LC}_{50}$ values above $250 \mu \mathrm{g} / \mathrm{mL}$. On the other hand, PCG-H $\left(80<\mathrm{LC}_{50}<250 \mu \mathrm{g} / \mathrm{mL}\right)$ was categorized as moderately toxic, while PCG-E $\left(\mathrm{LC}_{50}<80 \mu \mathrm{g} / \mathrm{mL}\right)$ was considered as highly toxic, with its degree of toxicity close to that of the standard drug cyclophosphamide $\left(\mathrm{LC}_{50}=19.7 \mu \mathrm{g} / \mathrm{mL}\right)$. The results indicate the presence of toxic compounds in the zoanthid obtained from Guadalupe and they suggest caution in the use of P. caribaeorum as a folk remedy. The variations found in the extracts of the tested Pernambucan populations of P. caribaeorum corroborate previous reports that the toxic action of this zoanthid is not inherent to the species, but it is influenced by environmental conditions and associated organisms.

Key words: Artemia salina; Organic extracts; Pernambuco; Toxicity; Zoanthidea

\section{Introduction}

The marine environment covers about $70 \%$ of the earth's surface and it is one of the richest ecosystems in terms of biological diversity. According to the World Register of Marine Species (WoRMS) (APPELTANS et al., 2010), roughly 230,000 marine species are known to science, the vast majority of which comprises benthic invertebrates. These animals are continuously involved in a large number of ecological interactions and, therefore, they need to defend themselves from pathogens and predators, as well as to compete for space, light, and nutrients (HARPER et al., 2001). This vast biodiversity is reflected in the chemical diversity, which constitutes a virtually unlimited source of new compounds for biomedical research and the development of potential drug candidates (HAEFNER, 2003).

Natural marine products are part of the social, economic, and cultural activities of coastal communities in Brazil. Some of these products are employed by the food and cosmetic industries, besides folk medicine. The use of plants and animals as remedies is an ancient and geographically widespread cross-cultural phenomenon. The Northeastern region has the longest extension of tropical coast in Brazil and marine animal-based remedies constitute the integral part of folk medicine in this region. Records on the use of marine organisms as medicinal resources date back to the $17^{\text {th }}$ century (ALMEIDA, 2007).

Currently, species from the class Bivalvia, such as Anomalocardia brasiliana, Mytella falcata, and Iphigenia brasiliana are used by fishermen communities from the Santa Cruz channel, in the town of Igarassu, on the northern coast of the state of Pernambuco (Northeastern Brazil), as healing, coagulant, fortifying, and aphrodisiac agents (COSTA-NETO, 2006). The spotfin porcupinefish (Diodon hystrix) is another organism used as a food source and medicinal agent along the whole coast of Pernambuco, and it is recognized for its high degree of toxicity. The fat extracted from this fish is used as a folk remedy for the treatment of arthritis and rheumatism (SILVA et al., 2004). Moreover, species from the phylum Cnidaria, especially anthozoans, figure among the different marine organisms used by the coastal communities of Pernambuco for folk remedies.

The zoanthid Palythoa caribaeorum (Duchassaing \& Michelotti, 1860) is an exclusively marine colonial species that inhabits the beach rocks along the coast of Pernambuco, and it is very common on the beaches of Porto de Galinhas, Piedade, Guadalupe, and Suape (SOARES et al., 2006). Its polyps produce mucus that protects the colony from desiccation, and it is used by fishing communities as an anesthetic and antiinflammatory agent, as well as for the treatment of topical wounds (SOARES et al., 2006).

Zoanthids of this genus are also known for the production of palytoxin, a potent marine toxin (MOORE; SCHEUER, 1971; GLEIBS et al., 1995). Recent cases of human intoxication by palytoxin have been reported. In Germany (HOFFMANN et al., 2008) and the USA (DEEDS; SCHWARTZ, 2010), poisoning occurred through dermal absorption, after victims touched zoanthid corals in their home aquariums. However, these animals, which are widely distributed among the beaches of Pernambuco, do not represent a risk to local tourists 
and there are no records of intoxication of fishermen due to the handling and use of the mucus produced by this zoanthid in folk remedies. An assessment of acute toxicity in mice of $P$. caribaeorum collected from the Porto de Galinhas beach (southern coast of Pernambuco) revealed a median lethal concentration greater than $2,000 \mathrm{mg} / \mathrm{kg}$ for the hydroalcoholic extract (intraperitoneal administration), indicating the absence of toxicity (SOARES et al., 2006).

Due to the considerable abundance and ease of collecting $P$. caribaeorum on the coast of Pernambuco, along with folk knowledge regarding its therapeutic actions, the indiscriminate use of the products of this zoanthid has been encouraged (mainly by fishermen communities) for the preparation of remedies such as anti-inflammatory and analgesic agents for the treatment of bruises and rheumatism. The assessment of the toxicity of organic extracts from this organism is important to the determination of its biological potential, as well as orientation with regard to the adequate use of this product and the prevention of possible intoxication. Ethanol extracts of $P$. caribaeorum collected from the Porto de Galinhas beach have shown analgesic activity on the writhing test (SOARES et al., 2006).

Due to the current tendency towards limiting the use of laboratory animals in toxicological tests and the fact that larvae of the crustacean Artemia salina are sensitive to a variety of substances, the brine shrimp bioassay has been used as a quick and simple test for predicting the toxicity of plant and/or animal extracts, as well as compounds with biological activity (SOLIS et al., 1993; KANWAR, 2007; GHISALBERTI, 2008). This methodology has been successfully employed in the detection of the marine algae toxicity, the screening of fungal toxins, assessment of the effects of exposure to heavy metals and pesticides (NUNES et al., 2006), and monitoring for the isolation of bioactive substances found in natural products (MOSHI; MBWAMBO, 2005).

The aim of this study was to assess the brine shrimp toxicity of hexane and ethanol extracts of $P$. caribaeorum collected from the Piedade, Guadalupe, and Suape beaches on the coast of Pernambuco, Brazil.

\section{Materials and Methods}

\section{Animal material}

About $1 \mathrm{~kg}$ of colonies of $P$. caribaeorum (Figure 1) was collected with the aid of a spatula, in the morning at low tide. Sampling took place in October 2006, at three different beaches located on the southern coast of Pernambuco - Piedade ( $8^{\circ} 11^{\prime} 2.4^{\prime \prime} \mathrm{S} ; 34^{\circ} 55^{\prime} 3.3^{\prime \prime} \mathrm{W}$ ), Guadalupe ( $8^{\circ} 40^{\prime} 13$ 'S; 35 $5^{\circ}$ '14"W), and Suape (8'23'6"S; 34'57'22.6"W) (Figure 2). The samples were placed in duly identified plastic bags and kept cool on ice prior to transportation to the laboratory. Identification was confirmed by zoologist Carlos Daniel Pérez from Universidade Federal de Pernambuco (UFPE). Voucher specimens were deposited in the collection of the Anthozoan Research Group (GPA/UFPE), under the numbers 501, 502, and 503.

FIGURE 1: Palythoa caribaeorum. a. Colonies arranged in patches on the reef surface; b. Open polyps (submerged colonies); c. Retracted polyps (exposed colonies).

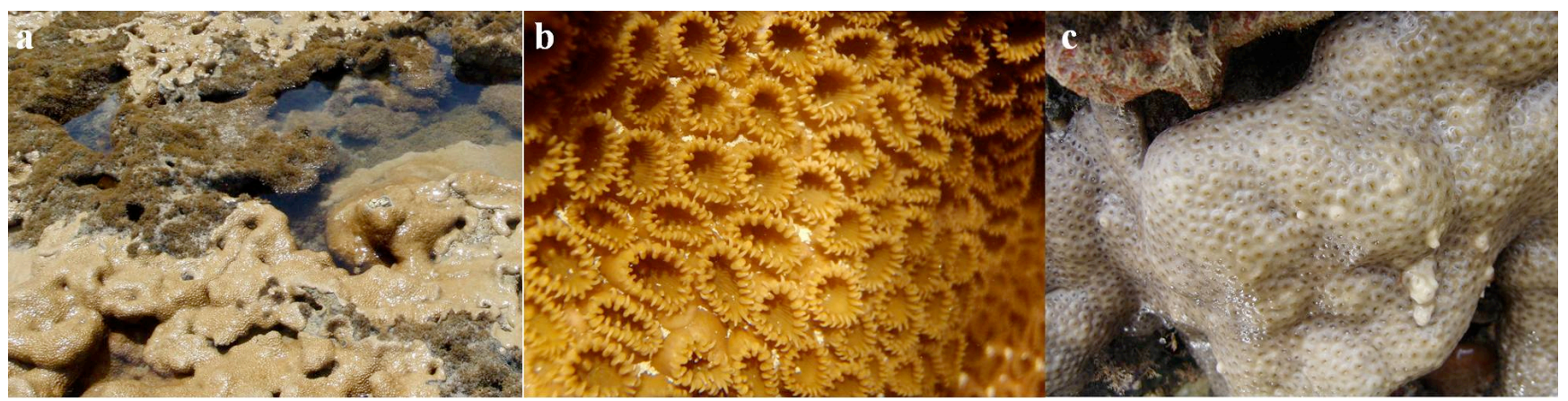


FIGURE 2: Beaches located on the southern coast of the state of Pernambuco, chosen as the study areas. a. Piedade; b. Guadalupe; c. Suape.

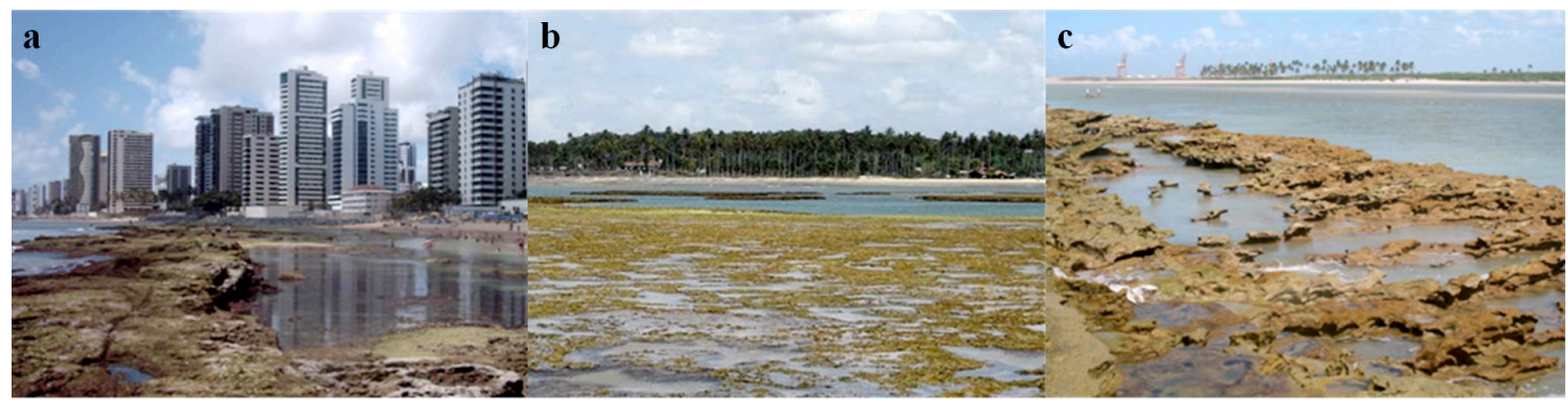

\section{Preparation of extracts}

Tissues from the specimens collected from the Piedade, Guadalupe, and Suape beaches were separately dried in an oven at $50^{\circ} \mathrm{C}$ for three days and, then, finely powdered using a mortar and pestle. The powder (Piedade: 415g; Suape: 320g; Guadalupe: 315g) was placed in a glass and, for each extraction, $500 \mathrm{~mL}$ of hexane was added to cover all animal material. Cold maceration was carried out for 72 hours with 24-hour intervals to ensure the extraction of the largest number of substances from the zoanthid tissues. The system was filtered and evaporated at reduced pressure to minimize possible degradation of the chemical constituents at high temperatures. After removal of the solvent, crude hexane extract was obtained and designated PCP-H, PCG-H, and PCS-H (hexane extract of $P$. caribaeorum from the Piedade, Guadalupe, and Suape beaches, respectively). The same procedure was repeated using ethanol $(500 \mathrm{~mL}$ per extraction) as the solvent to obtain crude ethanol extracts (PCP-E, PCG-E, and PCS-E).

\section{Artemia salina assay}

The procedure for $A$. salina toxicity assay followed the method developed by Solis et al. (1993), with modifications. Commercially available $A$. salina eggs, artificial salt, and cyclophosphamide were used. The eggs were incubated in a conical flask containing $500 \mathrm{~mL}$ of marine salt solution (2.5\%) and exposed to a 45-W lamp for two days for hatching. The flasks were aerated with an air pump and kept in a water bath at 30 $\pm 2^{\circ} \mathrm{C}$. The hexane and ethanol extracts were separately dissolved in distilled water and $2 \%$ aqueous Tween 80 to obtain a stock solution $(1 \mathrm{mg} / \mathrm{mL})$ for the preparation of the different concentrations used in the bioassays. The concentrations of the $P$. caribaeroum hexane extract ranged from 25 to $1,200 \mu \mathrm{g} / \mathrm{mL}$; those of the ethanol extract ranged from 5 to $1,100 \mu \mathrm{g} / \mathrm{mL}$; and those of the positive control ranged from 2 to $45 \mu \mathrm{g} / \mathrm{mL}$. An aliquot of each concentration $(1 \mathrm{~mL})$ was transferred to sterile universal vials and $9 \mathrm{~mL}$ of marine salt solution was added. A completely randomized design was used, with each concentration tested in triplicate: ten shrimp nauplii were transferred to each vial (30 nauplii per concentration). Control tubes with $2.5 \%$ marine salt solution and $2 \%$ aqueous Tween 80 did not contain the hexane or ethanol extracts. Cyclophosphamide was used as the standard test drug. After $24 \mathrm{~h}$, the number of survivors was counted using a stereomicroscope.

Mortality data obtained from these experiments were submitted to Probit analysis using the Statistical Analysis Software, version 9.1 (SAS INSTITUTE, 2002) for the determination of the lethal concentration for $50 \%$ nauplius population $\left(\mathrm{LC}_{50}\right)$, with a 95 percent confidence level for all experiments. Toxicity of the extracts was compared having the method described by Dolabela (1997) as a basis: $\mathrm{LC}_{50}<80 \mu \mathrm{g} / \mathrm{mL}$ was considered highly toxic; $\mathrm{LC}_{50}$ between 80 and $250 \mu \mathrm{g} / \mathrm{mL}$ was considered moderately toxic; and $\mathrm{LC}_{50}>250 \mu \mathrm{g} / \mathrm{mL}$ was considered mildly toxic or non-toxic.

\section{Results and Discussion}

The hexane and ethanol extract yields obtained from $P$. caribaeroum collected from three different 
beaches on the coast of Pernambuco ranged from 0.41 to $1.12 \%(\mathrm{w} / \mathrm{w})$ and 0.81 to $1.08(\mathrm{w} / \mathrm{w})$, respectively. The yields varied depending on the type of solvent and collection site. The greatest hexane/ethanol extract yields were obtained from colonies collected at Suape $(1.12 \% / 1.08 \%)$, followed by those from Guadalupe $(0.85 \% / 0.81 \%)$ and Piedade $(0.41 \% / 0.89 \%)$. The differences between extract yields may be related to genetic factors and the micro-environmental conditions of the different collection sites, such as luminosity, salinity, $\mathrm{pH}$, and age of the animals (HAY, 1996).

The results of $A$. salina lethality of the $P$. caribaeorum organic extracts revealed a dose-response relationship to a greater or lesser extent. Table 1 displays the degree of toxicity of the ethanol and hexane extracts of $P$. caribaeorum collected from the Piedade, Guadalupe, and Suape beaches.

The degree of toxicity varied depending on the kind of solvent (hexane or ethanol) and collect site (Piedade, Guadalupe, or Suape beach). The lowest estimated $\mathrm{LC}_{50}$ values were detected in samples collected from Guadalupe $(\mathrm{PCG}-\mathrm{H}=188.7 \mu \mathrm{g} / \mathrm{mL}$ and $\mathrm{PCG}-\mathrm{E}=$ $24.2 \mu \mathrm{g} / \mathrm{mL})$, classifying these extracts as moderately and highly toxic, respectively (DOLABELA, 1997). The lethality values demonstrate that all other extracts were virtually non-toxic to brine shrimp $\left(\mathrm{LC}_{50}>250 \mu \mathrm{g} /\right.$ $\mathrm{mL}$ ). The order of toxicity for the extracts from samples collected at the Piedade and Suape beaches was PCP-E $>$ PCP-H > PCS-H > PCS-E. Comparing the hexane and ethanol extracts of the samples collected at Piedade (PCP-H $=414.6 \mu \mathrm{g} / \mathrm{mL}$ and PCP-E $=333.5 \mu \mathrm{g} / \mathrm{mL})$, greater toxicity was determined for the ethanol extract, but the confidence intervals overlapped. For the samples collected from Suape (PCS-H = 625.8 and PCS-E = $725.5 \mu \mathrm{g} / \mathrm{mL}$ ), the greatest toxicity was presented by the hexane extract, but the confidence intervals overlapped again. This finding suggests that extracts from different beaches may have different chemical constituents that are possibly associated with these response variations, along with the influence of biotic and abiotic factors at the different beaches.

The three study sites have different features: Piedade is an urban beach influenced by human activities; Guadalupe is an environmentally protected area; and Suape is a beach under the influence of an industrial port complex. The results of this study confirm the hypothesis that different forms of environmental pressure exert a direct influence over the biosynthesis of secondary metabolites and are responsible for either the production or inhibition of toxic substances, as well as

TABLE 1: Brine shrimp toxicity of organic extracts of Palythoa caribaeorum.

\begin{tabular}{|c|c|c|c|c|}
\hline $\begin{array}{c}\text { Zoanthid } \\
\text { extract }\end{array}$ & $\begin{array}{c}\text { Equation } \\
(95 \% \text { CI for } \beta)\end{array}$ & $\begin{array}{c}\mathrm{LC}_{50}(\mu \mathrm{g} / \mathrm{mL}) \\
(95 \% \mathrm{CI})\end{array}$ & $\chi^{2}$ & $\mathbf{T R}_{50}$ \\
\hline CYCLO & $\begin{aligned} \mathrm{Y}= & -4.61+3.57 \log \mathrm{x} \\
& (3.16-3.97)\end{aligned}$ & $\begin{array}{c}19.7 \\
(17.3-22.1)\end{array}$ & 2.83 & - \\
\hline PCG-E & $\begin{aligned} \mathrm{Y}= & 1.54+2.49 \log \mathrm{x} \\
& (2.23-2.74) \mathrm{a}\end{aligned}$ & $\begin{array}{c}24.2 \\
(20.3-28.7) a\end{array}$ & 1.40 & 1.23 \\
\hline PCG-H & $\begin{aligned} \mathrm{Y}= & -0.42+2.38 \log \mathrm{x} \\
& (2.08-2.67) \mathrm{a}\end{aligned}$ & $\begin{array}{c}188.7 \\
(148.9-233.4) b\end{array}$ & 2.65 & 9.59 \\
\hline PCP-E & $\begin{aligned} \mathrm{Y}= & -4.19+3.64 \log \mathrm{x} \\
& (3.19-4.08) \mathrm{b}\end{aligned}$ & $\begin{array}{c}333.5 \\
(261.7-423.6) c\end{array}$ & 8.77 & 16.96 \\
\hline РCP-H & $\begin{aligned} \mathrm{Y}= & -3.41+3.21 \log \mathrm{x} \\
& (2.81-3.61) \mathrm{b}\end{aligned}$ & $\begin{array}{c}414.6 \\
(322.9-523.2) \mathrm{c}\end{array}$ & 7.55 & 21.09 \\
\hline PCS-H & $\begin{aligned} Y= & 1.36+3.54 \log x \\
& (3.12-3.96) b\end{aligned}$ & $\begin{array}{c}625.8 \\
(502.8-804.9) \mathrm{cd}\end{array}$ & 11.71 & 31.84 \\
\hline PCS-E & $\begin{aligned} \mathrm{Y}= & -14.5+5.07 \log \mathrm{x} \\
& (4.33-5.80) \mathrm{c}\end{aligned}$ & $\begin{array}{c}725.5 \\
(572.8-924.9) \mathrm{d}\end{array}$ & 8.35 & 36.91 \\
\hline
\end{tabular}

PCG-E and PCG-H = ethanol and hexane extracts from Guadalupe; PCP-E and PCP-H = ethanol and hexane extracts from Piedade; PCS-H and PCS-E = hexane and ethanol extracts from Suape; CYCLO = positive control, cyclophosphamide; $\mathrm{LC}_{50}=$ lethal concentration; $\mathrm{CI}=$ confidence interval; $\chi^{2}=$ chi-square test; TR $=$ toxicity ratio, calculated based on Robertson and Preisler (1992); different lowercase letters denote statistically significant differences in $\mathrm{LC}_{50}$ values $(\mathrm{p}<0.05 \%)$. 
changes in the chemical structure of bioactive molecules (CORREIA et al., 2002).

Toxicity is a widespread phenomenon in coral reef organisms, possibly as a result of evolutionary pressures imposed by the environment, such as a high degree of biodiversity associated to competition for space. $P$. caribaeorum is an aggressive competitor for space and, although the density of its colonies is directly influenced by variations in environmental conditions, its growth rates ( 2.5 to $4 \mathrm{~mm}$ /day) remain constant (SUCHANEK; GREEN, 1981; SOTO, 2007). As more preserved environments exhibit a greater degree of biodiversity, there is an increase in competition among sessile organisms, which, due to their inability for locomotion, rely on the production of secondary metabolites as their chemical weapons. This may explain why the highest degree of toxicity occurred in the most preserved area (Guadalupe beach). In addition, it is known that there is a variety of microorganisms, including bacteria (CAMPOS, 2011), that live in association with $P$. caribaeorum colonies and they could eventually produce toxic substances. Both the composition of the associated microbial community and the toxins produced could also change according to the different environments.

To sum it up, the finding that some populations of P. caribaeorum on the southern coast of Pernambuco are non-toxic ones corroborates reports that the toxicity of this zoanthid is not inherent to the species, but it can be influenced by environmental conditions and associated organisms (MOORE et al., 1982; ELYAKOV et al., 1994; TANIYAMA et al., 2003; SOARES et al., 2006).

The A. salina assay is an excellent method for preliminary toxicity investigations for the screening of medicinal plant extracts used as folk remedies and for indicating a great variety of biologically active compounds (QUIGNARD et al., 2003). The results of this study for colonies of $P$. caribaeorum collected from different beaches are similar to those reported by Soares et al. (2006) for specimens collected from the Porto de Galinhas beach, which is also on the southern coast of the state of Pernambuco. The exception was the sample from Guadalupe (PCG-E), which proved to be highly toxic, as demonstrated by the lowest $\mathrm{LC}_{50}$ values among all the extracts tested. Moreover, the PCG-E achieved lethality comparable to that of the positive control (cyclophosphamide). Therefore, among the extracts obtained from specimens of $P$. caribaeorum collected from different sites on the southern coast of Pernambuco, those from the Guadalupe beach showed the greatest likelihood for containing potentially cytotoxic substances.

\section{Acknowledgements}

The authors thank the fisherman Andre (Suape beach) for his invaluable assistance during field work. This work was funded and supported by the Foundation of Support to Sciences and Technology of Pernambuco (FACEPE) APQ 2008 0845-2.10/08.

\section{References}

ALMEIDA, A. V. Zooterapia indígena brasileira no século XVI nas obras de Guilherme Piso, Georg Marcgrave e Johannes de Laet. Sitientibus, Série Ciências Biológicas, Feira de Santana, v. 7, n. 3, p. 261-272, 2007.

APPELTANS, W.; BOUCHET, P.; BOXSHALL, G. A.; FAUCHALD, K.; GORDON, D. P.; HOEKSEMA, B. W.; POORE, G. C. B.; VAN SOEST, R. W. M.; STÖHR, S.; WALTER, T. C.; COSTELLO, M. J. (Ed.). World register of marine species. 2010. Disponível em <http://www.marinespecies.org >. Acesso em: 15 jun. 2010.

CAMPOS, F. F. Diversidade de bactérias associadas ao muco do zoantídeo Palythoa caribaeorum (Cnidaria, Anthozoa) do litoral sul de Pernambuco. 2011. 87 f. Dissertação (Mestrado em Saúde Humana e Meio Ambiente) - Universidade Federal de Pernambuco, Vitória de Santo Antão. 2011.

CORREIA, C. R. D.; COSTA, P. R. R.; FERREIRA, V. F. Vinte e cinco anos de reações, estratégias e metodologias em química orgânica. Química Nova, São Paulo, v. 25, Supl. 1, p. 82-89, 2002. COSTA-NETO, E. M. Os moluscos na zooterapia: medicina tradicional e importância clínico-farmacológica. Biotemas, Florianópolis, v. 19, n. 3, p. 71-78, 2006.

DEEDS, J. R.; SCHWARTZ, M. D. Human risk associated with palytoxin exposure. Toxicon, Oxford, v. 56, n. 2, p. 150-162, 2010. DOLABELA, M. F. Triagem in vitro para atividade antitumoral e anti-Tripanossoma cruzi de extratos vegetais, produtos naturais e substâncias sintéticas. 1997. 128 f. Dissertação (Mestrado em Ciências Biológicas - Farmacologia) - Universidade Federal de Minas Gerais, Belo Horizonte. 1997.

ELYAKOV, G. B.; KUZNETSOVA, T. A.; STONIK, V. A.; MIKHAILOV, V. V. New trends of marine biotechnology development. Pure and Applied Chemistry, Research Triangle Park, v. 66, n. 4, p. 811-818, 1994. 
GHISALBERTI, E. L. Detection and isolation of bioactive natural products. In: COLEGATE, S. M.; MOLYNEUX, R. J. (Ed.). Bioactive natural products - Detection, isolation, and structural determination. 2. ed. Boca Raton: CRC Press, 2008. p. 11-76.

GLEIBS, S.; MEBS, D.; WERDING, B. Studies on the origin and distribution of palytoxin in a Caribbean coral reef. Toxicon, Oxford, v. 33, n. 11, p. 1531-1537, 1995.

HAEFNER, B. Drugs from the deep: marine natural products as drug candidates. Drug Discovery Today, London, v. 8, n. 12, p. 536-544, 2003.

HARPER, M. K.; BUGNI, T. S.; COPP, B. R.; JAMES, R. D.; LINDSAY, B. S.; RICHARDSON, A. D.; SCHNABEL, P. C.; TASDEMIR, D.; VANWAGONER, R. M.; VERBITSKI, S. M.; IRELAND, C. M. Introduction to the chemical ecology of marine natural products. In: MCCLINTOCK, J. B.; BAKER, B. J. (Ed.). Marine chemical ecology. Boca Raton: CRC Press, 2001. p. 3-69.

HAY, M. E. Marine chemical ecology: what's known and what's next? Journal of Experimental Marine Biology and Ecology, Amsterdam, v. 200, p. 103-134, 1996.

HOFFMANN, K.; HERMANNS-CLAUSEN, M.; BUHL, C.; BUCHLER, M. W.; SCHEMMER, P.; MEBS, D.; KAUFERSTEIN, $\mathrm{S}$. A case of palytoxin poisoning due to contact with zoanthid corals through a skin injury. Toxicon, Oxford, v. 51, n. 8, p. 1535-1537, 2008.

KANWAR, A. S. Brine shrimp (Artemia salina) - a marine animal for simple and rapid biological assays. Journal of Chinese Clinical Medicine, Beijing, v. 2, n. 4, p. 236-240, 2007.

MOORE, R. E.; HELFRICH, P.; PATTERSON, G. M. L. The deadly seaweed of Hana. Oceanus, Woods Hole, v. 25, n. 2, p. 5463, 1982.

MOORE, R. E.; SCHEUER, P. J. Palytoxin - new marine toxin from a coelenterate. Science, Washington, v. 172, n. 3982, p. 495498, 1971

MOSHI, M. J.; MBWAMBO, Z. H. Some pharmacological properties of extracts of Terminalia sericea root. Journal of Ethnopharmacology, Limerick, v. 97, n. 1, p. 43-47, 2005.

NUNES, B. S.; CARVALHO, F. D.; GUILHERMINO, L. M.; STAPPEN, G. Use of the genus Artemia in ecotoxicity testing. Environmental Pollution, Barking, v. 144, n. 2, p. 453-462, 2006.
QUIGNARD, E. L.; POHLIT, A. M.; NUNOMURA, S. M.; PINTO, A. C.; SANTOS, E. V.; MORAIS, S. K.; ALECRIM, A. M.; PEDROSO, A. C.; CYRINO, B. R.; MELO, C. S.; FINNEY, E. K.; GOMES, E. O.; SOUZA, K. S.; OLIVEIRA, L. C.; DON, L. C.; SILVA, L. F.; QUEIROZ, M. M.; HENRIQUE, M. C.; SANTOS, M.; PINTO, P. S.; SILVA, S. G. Screening of plants found in Amazonas state for lethality towards brine shrimp. Acta Amazonica, Manaus, v. 33, n. 1, p. 93-104, 2003.

ROBERTSON, J. L.; PREISLER, H. K. Pesticide bioassays with arthropods. Boca Raton: CRC Press, 1992. 127 p.

SAS INSTITUTE. SAS User's Guide: Statistics. Version 9.1. Cary: SAS Institute, 2002.

SILVA, M. L. V.; ALVES, A. G. C.; ALMEIDA, A. V. A zooterapia no Recife (Pernambuco): uma articulação entre as práticas e a história. Biotemas, Florianópolis, v. 17, n. 1, p. 95-116, 2004.

SOARES, C. L. S.; PÉREZ, C. D.; MAIA, M. B. S.; SILVA, R. S.; MELO, L. F. A. Avaliação da atividade anti-inflamatória e analgésica do extrato bruto hidroalcoólico do zoantídeo Palythoa caribaeorum (Duchassaing \& Michelotti, 1860). Revista Brasileira de Farmacognosia, Curitiba, v. 16, n. 4, p. 463-468, 2006.

SOLIS, P. N.; WRIGHT, C. W.; ANDERSON, M. M.; GUPTA, M. P.; PHILLIPSON, D. A microwell cytotoxicity assay using Artemia salina (Brine shrimp). Planta Medica, New York, v. 59, n. 3, p. 250-252, 1993.

SOTO, V. A. Effects of sedimentation on the distribution and ecology of the reef zoanthid Palythoa caribaeorum. 2007. $83 \mathrm{f}$. Dissertação (Master of Science in Marine Sciences) - University of Puerto Rico, Mayaguez. 2007.

SUCHANEK, T. H.; GREEN, D. J. Interespecific competition between Palythoa caribaeorum and other sessile invertebrates on St. Croix Reefs, U.S. Virgin Islands. In: INTERNATIONAL CORAL REEF SYMPOSIUM, v. 2, 4, 1981, Manila. Disponível em <http://www.aoml.noaa.gov/general/lib/CREWS/Cleo/St.\%20 Croix/salt_river85.pdf $>$. Acesso em: 22 jun. 2010.

TANIYAMA, S.; ARAKAWA, O.; TERADA, M.; NISHIO, S.; TAKATANI, T.; MAHMUD, Y.; NOGUCHI, T. Ostreopsis sp., a possible origin of palytoxin (PTX) in parrotfish Scarus ovifrons. Toxicon, Oxford, v. 42, n. 1, p. 29-33, 2003. 